\title{
HUBUNGAN PENGETAHUAN DESAIN BUSANA DENGAN HASIL MENGGAMBAR BUSANA KREASI PADA SISWA SMK NEGERI 8 MEDAN
}

\author{
${ }^{1}$ Dame Elfrida Sianturi \\ ${ }^{2}$ Dra. Rasita Purba, M.Kes \\ rasitapurba@gmail.com
}

\begin{abstract}
ABSTRAK
Penelitian ini bertujuan untuk mengetahui hubungan yang positif dan signifikan antara Pengetahuan Desain Busana dengan Hasil Menggambar Busana Kreasi Pada Siswa SMK Negeri 8 Medan. Populasi penelitian ini adalah seluruh siswa kelas XI SMK Negeri 8 Medan yang berjumlah 131 orang siswa. Sampel penelitian diambil dengan teknik purposive sampling sehingga ditentukan kelas $\mathrm{XI}^{2}$ sebagai subjek penelitian yang berjumlah 31 orang siswa. Data penelitian dikumpul dengan menggunakan tes pengetahuan Desain Busana dan lembar pengamatan Hasil Menggambar Busana Kreasi .Berdasarkan data hasil penelitian diperoleh hasil analisis data korelasi Hasil Menggambar Busana Kreasi atas Pengetahuan Desain Busana, ternyata memiliki bentuk hubungan linier, yaitu : $\hat{Y}=18,18+0,10 X$ yang dibuktikan dengan nilai $F_{\text {Hitung }} 0,98<$

$\mathrm{F}_{\text {Tabel }}$ 2,38 sehingga persamaan regresi tersebut adalah linier. Selanjutnya untuk uji keberartian regresi diperoleh $\mathrm{F}_{\text {Hitung }}$ 7,65 $>\mathrm{F}_{\text {Tabel }}$ 4,18 sehingga persamaan regresi $\mathrm{Y}$ atas $\mathrm{X}$ adalah berarti. Apabila dilanjutkan pada analisis koefisien korelasi antara Y dan X, maka nilai koefisien korelasi sebesar 0,457 dan $\mathrm{r}_{\text {Tabel }}$ untuk jumlah responden sebanyak 31 orang sebesar 0,355 pada taraf signifikansi 5\%. Dengan demikian diperoleh $\mathrm{r}_{\text {hitung }}$ 0,457 > $\mathrm{r}_{\text {Tabel }}$ 0,355 sehingga koefisien korelasi $\mathrm{X}$ terhadap $\mathrm{Y}$ adalah signifikan. Selanjutnya, hasil analisis keberartian koefisien korelasi antar variabel $\mathrm{X}$ dengan $\mathrm{Y}$ diperoleh nilai $\mathrm{t}_{\mathrm{Hitung}}$ sebesar 2,77 dan dikonsultasikan dengan nilai $\mathrm{t}_{\text {Tabel }(\mathrm{dk}=29 ; \alpha=0,05)}$ sebesar 2,04 sehingga diperoleh $\mathrm{t}_{\text {Hitung }} 2,77>\mathrm{t}$ Tabel 2,04 . Sesuai dengan hal tersebut dapat dikatakan bahwa terdapat korelasi yang berarti antara variabel X dengan Y. Dengan demikian dapat dijelaskan bahwa terdapat kontribusi fungsional yang signifikan antara Pengetahuan Desain Busana (X) dengan Hasil Menggambar Busana Kreasi (Y). Bentuk kontribusi tersebut berarah positif, berarti bahwa semakin baik Pengetahuan Desain Busana maka Hasil Menggambar Busana Kreasi akan semakin tinggi pula, begitu juga sebaliknya.
\end{abstract}

\section{Kata Kunci:Pengetahuan Desain Busana}

\section{Pendahuluan}

Perkembangan ilmu pengetahuan dan tekknologi yang semakin pesat menuntut manusia terus mengembangkan wawasan dan kemampuan diberbagai bidang. Busana merupakan segala sesuatu yang dikenakan dari ujung rambut hingga ujung kaki. Menurut Wasia Rusbani (2001), busana disamping sebagai syarat kesehatan, juga berfungsi sebagai penutup tubuh, melindungi tubuh, menambah nilai estetika, memiliki rasa keindahan, memenuhi syarat peradapan dan kesusilaan. Jenis busana dibagi menjadi bermacammacam fungsi serta kegunaannya. Jenis busana, yaitu, sesuai kesempatan pemakai ( pesta, kerja, santai dan lain-lain).

Seiring dengan perkembangan jaman, mode busana yang adapun semakin berkembang sesuai dengan perkembangan mode yang beraneka ragam, baik warna, model, bahan dan teknik pembuatan. Para perancang busana selalu menampilkan mode serta trend warna terbaru yang simple dan menarik konsumen. Busana yang mereka tampilkan dalam acara pameran peragaan busana pada umumnya diambil dari pemanfaatan limbah seperti kaleng minuman, keeping VCD, kerang, sisik ikan, kantong plastic, gelas plastic minuman ( agua, ades, total ), ( Rusmawati, 2010 ) yang disebut dengan busana kreasi.

Busana kreasi adalah busana yang dibuat sebagai hasil daya cipta, gagasan, idea atau inspirasi seseorang yang dibuat dari bahan-bahan yang tidak lazim dipegunakan sebagai inspirasi dalam suatu rancangan busana, dengan kreativitas yang tinggi, kita dapat memanfaatkan bahan-bahan yang sudah tidak terpakai serta tidak layak dipergunakan sebagai sumber ide dalam menggambar suatu busana kreasi yang indah dan menarik.

Menurut Sipahelut (2000) menggambar adalah perwujudan dari pengembangan ide-ide yang ada dalam pikiran perancang yang dituangkan pada kertas secara spontan dan secepat mungkin. Menggambar busana kreasi merupakan perwujudan gambar/ desain yang mewakili idea atau kreativitas yang ada pada diri seseorang dan mengeksplotasinya menjadi sesuatu yang baru yang memanfaatkan 

medan

limbah sebagai inspirasi. Limbah gelas plastic aqua ades merupakan salah satu bahan multi guna yang sangat banyak digunakan dalam kehidupan seharihari. Gelas plastic aqua ades dapat menjadi sumber ide yang menarik, dapat digunakan sebagai penghias busana atau pengganti bahan utama utama busana (pada seluruh busana ) dalam pembuatan suatu gambar desain busana ( Rusmawati, 2010 ).

Menggambar suatu busana didasari dengan adanya pengetahuan tentang desain busana. Dalam menggambar suatu busana kreasi dengan sumber ide gelas plastik, selain memiliki kreativitas yang tinggi juga harus memiliki pengetahuan desain busana yang baik. Dalam program studi tata busana di SMK, terdapat mata pelajaran menggambar busana yang berfungsi untuk mengembangkan kemampuan siswa dalam merancang busana yang akan menjadi bekalnya untuk memasuki dunia kerja bidang fashion designer. Melalui mata pelajarann menggambar busana ini diharapkan siswa SMK mampu dalam menghasilkan suatu rancangan busana kreasi. Menurut Poespo (2006) sebuah rancangan yang baik mampu tampil secara lebih professional dan kreatif, oleh karenanya poespo (2006) menyarankan agar siswa SMK memperluas pengetahuannya dibidang menggambar busana. Selanjutnya Muliawan (2002) menjelaskan bahwa factor terpenting dalam dunia mode busana wanita adalah fashion drawing yang berarti menggambar busana. Oleh karena itu siswa perlu lebih mendalami pengetahuan desain busana agar hasil menggambar busananya baik.

Berdasarkan penjabaran di atas, bahwa pengetahuan desain busana penting dalam mengekspresikan suatu gagasan atau sumber ide seperti gelas plastic aqua ades, yang menghasilkan suatu gambar rancangan busana kreasi. Siswa pada materi menggambar busana, mengalami kesulitan dalam menuangkan gagasan atau ide-ide menjadi sebuah gambar busana kreasi. Sementara pada pembelajaran sebelumnya mereka sudah mendapatkan materi yang berkenaan dengan itu yaitu mengenai dasar seni dan desain, jenis-jenis busana, bagian-bagian busana, menggambar busana dalam berbagai kesempatan, dan lain-lain. Harapannya apabila pengetahuan desain busana dipahami oleh siswa secara maksimal, maka akan sangat baik untuk menstimulus siswa dalam mengembangkan potensi dan kreatifitasnya dalam menggambar busana kreasi.

Berdasarkan latar belakang yang telah diuraikan diatas, maka peneliti sangat tertarik untuk melakukan penelitian dengan judul: "Hubungan Pengetahuan Desain Busana Dengan Hasil Menggambar Busana Kreasi Pada Siswa Kelas XI Jurusan Tata Busana SMK Negeri 8 Medan Tahun Ajaran 2012/2013", maka penulis akan mengadakan penelitian sejauh mana hubungan pengetahuan desain busana dengan hasil menggambar busana kreasi oleh siswa kelas XI Jurusan Tata Busana SMK Negeri 8 Medan.

Berdasarkan latar belakang yang telah diuraikan di atas, maka tampaklah adanya kesenjangan antara harapan dan kenyataan dimana penulis mengharapkan agar peserta didik menguasai pengetahuan desain busana agar dapat mendukung kemampuan menggambar busana kreasinya. Karena pentingnya kemampuan dasar yang memadai agar proses belajar mengajar yang dilaksanakan lebih memuaskan maka penulis ingin melihat hubungan pengetahuan desain busana dengan hasil menggambar busana kreasi pada siswa SMK Negeri 8 Medan, yang problematika perlu dikaji secara ilmiah

Maka tujuan penelitian adalah sebagai berikut :

1. Untuk mengetahui tingkat kecenderungan pengetahuan desain busana siswa SMK Negeri 8 Medan.

2. Untuk mengetahui tingkat kecenderungan hasil menggambar busana kreasi SMK Negeri 8 Medan.

3. Untuk mengetahui hubungan pengetahuan desain busana dengan hasil menggambar busana kreasi pada siswa SMK Negeri 8 Medan

\section{Metode Penelitian}

Penelitian ini dilaksanakan di SMK Negeri 8 Medan. Waktu penelitian 10 Juni 2013. Sementara Uji coba instrumen dilakukan pada 15 Mei 2013 di SMK Negeri 10 Medan.

Populasi merupakan objek penelitian yang diharapkan dapat dijadikan sebagai sumber data yang diperlukan dalam penelitian. Pada penelitian ini yang menjadi populasi penelitian ini adalah siswa kelas XI SMK Negeri 8 Medan yang berjumlah 131 siswa. Sampel adalah sebagian dari populasi. Menurut Sugiyono (2006) sampel adalah sebagian dari jumlah dan karakteristik yang dimiliki oleh populasi tersebut. Mengingat banyaknya populasi penelitian serta keterbatasan peneliti untuk meneliti keseluruhan subjek tersebut maka pengambilan sampel dilakukan dengan teknik purposive sampling, dengan menggunakan teknik purposive sampling tersebut, maka siswa akan ditentukan kelas $\mathrm{XI}^{2}$ sebagai subjek penelitian yang berjumlah 31 orang siswa, penetapan sampel berdasarkan Sugiyono bahwa pengambilan sample bukan di dasarkan atas strata, random atau daerah tetapi didasarkan atas adanya tujuan tertentu maka di dapat informasi dari guru bahwa kelas $\mathrm{XI}^{2}$, memperoleh nilai yang terendah dari kelas lainnya.

Tes adalah sekumpulan pertanyaan untuk menjaring data dari Hubungan Pengetahuan Desain Busana (X). Dalam penelitian ini digunakan tes (pertanyaan) berbentuk pilihan ganda sebanyak 40 butir soal dari setiap pertanyaan yang disusun terdiri atas empat pilihan jawaban, dimana setiap empat pilihan jawaban yang jawabannya ( $a, b, c$, dan d). 
Hubungan pengetahuan desain busana dengan hasil Menggambar busana kreasi pada siswa Smk negeri 8 medan

Setiap item dijawab benar bernilai satu (1) sedangkan yang dijawab salah diberi nilai nol (0).

Validitas instrumen penelitian diuji dengan rumus korelasi poit biraserial dengan tingkat penerimaan signifikan $5 \%$ dari 40 soal. Diperoleh $\mathrm{r}$ tabel adalah 0,35. Dari 40 soal tes objektif yang disusun terdapat 30 soal yang dinyatakan valid dan 10 soal yang tidak valid. Realibilitas instrumen penelitian diuji dengan rumus Kudder Richarson (KR-21), dari hasil perhitungan diperoleh koefisien realibilitas tes objektif sebesar 0,886 .

Pengamatan menurut Narbuko (2001), pengamatan adalah pengumpulan data yang dilakukan dengan cara mengamati dan mencatat tentang gejala-gejala yang diselidiki. Instrumen pengumpulan data untuk mengukur tingkat hasil kemampuan siswa kelas XI di SMK Negeri 8 Medan dalam menggambar busana kreasi (Y), dengan pengamatan yang dilakukan oleh empat orang pengamat, dimana keempat pengamat tersebut dianggap sudah ahli dibidangnya, sebelum keempat pengamat tersebut melakukan pengamatan perlu dirumuskan suatu kesepakatan yang dimaksud untuk memperoleh data yang akurat sesuai dengan kesepakatan, adapun bobot skor dari setiap komponen yang disusun, terdiri atas empat pilihan yaitu: Skor 4= Sangat baik, Skor 3= Baik, Skor $2=$ Kurang, dan Skor 1= Kurang Sekali.

\section{HASIL PENELITIAN DAN PEMBAHASAN}

Instrumen penelitian ini diperoleh dari data variabel penelitian yaitu data Pengetahuan Desain Busana (X) dan Hasil Menggambar Busana Kreasi (Y). Berdasarkan pengolahan data akan diuraikan tentang deskripsi data. Kelas kecenderungan masing masing variabel penelitian, pengujian persyaratan analisis dan pengujian hipotesis.

\section{A. Deskripsi Data Penelitian}

\section{Pengetahuan Desain Busana $(X)$}

Berdasarkan data yang diperoleh dari hasil penelitian dengan jumlah responden 31 orang diperoleh nilai tertinggi 80 dan nilai terendah 40 , dengan nilai rata-rata sebesar 58,49; standar deviasi sebesar 12,44 dan varians sebesar 154,69. Distribusi frekuensi data variabel Pengetahuan Desain Busana dapat dilihat pada Tabel 5 dan perhitungan disajikan pada lampiran 12 halaman 103.

\begin{tabular}{|c|c|c|}
\hline Interval & $\mathbf{f i}$ & $\mathbf{F r}$ \\
\hline $40-46$ & 5 & $16 \%$ \\
\hline $47-53$ & 10 & $32 \%$ \\
\hline $54-60$ & 5 & $16 \%$ \\
\hline $61-67$ & 3 & $10 \%$ \\
\hline $68-74$ & 4 & $13 \%$ \\
\hline $75-81$ & 4 & $13 \%$ \\
\hline Jumlah & 31 & $100 \%$ \\
\hline
\end{tabular}

\section{Tabel 5. Distribusi Frekuensi Variabel Pengetahuan Desain Busana}

Berdasarkan sajian data pada Tabel 5 di atas, untuk kelas interval dengan rentang nilai di bawah nilai rata-rata berada pada kelas interval pertama dan kedua dengan jumlah responden sebanyak 15 orang atau sekitar $48 \%$ dari jumlah keseluruhan responden. Sedangkan untuk kelas interval dengan rentang nilai berada di atas nilai rata-rata berada pada kelas interval keempat keenam dengan jumlah responden sebanyak 11 orang atau sekitar $36 \%$ dari jumlah keseluruhan populasi yang berarti bahwa siswa memiliki pengetahuan desain busana.

\section{Hasil Menggambar Busana Kreasi (Y)}

Berdasarkan data yang diperoleh dari hasil penelitian dengan jumlah responden 31 orang terdapat skor tertinggi 28 dan skor terendah 19 , dengan rata-rata skor sebesar 24,16; standar deviasi sebesar 2,86 dan varians sebesar 8,20. Distribusi frekuensi data variabel Hasil Menggambar Busana Kreasi dapat dilihat pada Tabel 6 dan perhitungan disajikan pada lampiran 12 halaman 103

\begin{tabular}{|c|c|c|}
\hline Interval & fi & Fr \\
\hline $19-20$ & 6 & $19 \%$ \\
\hline $21-22$ & 3 & $10 \%$ \\
\hline $23-24$ & 5 & $16 \%$ \\
\hline $25-26$ & 10 & $32 \%$ \\
\hline $27-28$ & 7 & $23 \%$ \\
\hline Jumlah & 31 & $100 \%$ \\
\hline
\end{tabular}

Tabel 6. Distribusi Frekuensi Variabel Hasil Menggambar Busana Kreasi

Berdasarkan sajian data pada Tabel 6 di atas, untuk kelas interval dengan rentang nilai di bawah nilai rata-rata berada pada kelas interval pertama dan kedua dengan jumlah responden sebanyak 9 orang atau sekitar $29 \%$ dari jumlah keseluruhan responden. Sedangkan untuk kelas interval dengan rentang nilai berada di atas nilai rata-rata berada pada kelas interval keempat kelima dengan jumlah responden sebanyak 17 orang atau sekitar 55\% dari jumlah keseluruhan sampel yang berarti bahwa siswa memiliki kemampuan menggambar busana kreasi.

\section{B. Identifikasi Kecernderungan Variabel Penelitian \\ 1. Pengetahuan Desain Busana (X)}

Untuk mengidentifikasi tingkat kecenderungan data hasil penelitian digunakan ratarata absolut (Mo), rata-rata ideal (Mi) dan standar deviasi ideal (Sdi).

Berdasarkan data hasil penelitian Pengetahuan Desain Busana diperoleh Mo sebesar 58,49; Mi sebesar 50 dan Sdi sebesar 16,67. Berdasarkan hasil perhitungan diperoleh kelas kecenderungan Pengetahuan Desain Busana (X) 
Hubungan pengetahuan desain busana dengan hasil Menggambar busana kreasi pada siswa Smk negeri 8 medan

sebagai mana disajikan pada tabel 7. Perhitungan selengkapnya ada pada lampiran 13 halaman 105.

\begin{tabular}{|c|c|c|c|}
\hline Kelompok & fo & Fr & Kategori \\
\hline $75-$ Ke atas & 4 & $12,90 \%$ & Tinggi \\
\hline $50-74$ & 20 & $64,52 \%$ & Cukup \\
\hline $25-49$ & 7 & $22,58 \%$ & Kurang \\
\hline 24-ke bawah & 0 & $0,00 \%$ & Rendah \\
\hline Jumlah & 31 & $100,00 \%$ & \\
\hline
\end{tabular}

Tabel 7. Tingkat Kecenderungan Pengetahuan Desain Busana

Dari tabel 7 dilihat bahwa kategori tinggi ada 4 orang $(12,90 \%)$, kategori cukup ada 20 orang $(64,52 \%)$.

Dengan demikian dapat disimpulkan bahwa Persentasi Pengetahuan Desain Busana (X) pada Siswa SMK Negeri 8 Medan berada dalam kategori Cukup.Jadi dapat disimpulkan Mo > Mi yaitu 58,49\% > Mi 50. Dan berdasarkan hasil perhitungan tersebut dapat disimpulkan bahwa siswi kelas XI SMK Negeri 8 Medan mempunyai Pengetahuan Desain Busana (X) Berada dalam kategori cukup yang berarti bahwa data hasil penelitian mengenai Pengetahuan Desain Busana cenderung berada pada rata-rata ideal.

\section{Hasil Menggambar Busana Kreasi (Y)}

Untuk mengidentifikasi tingkat kecenderungan data hasil penelitian digunakan ratarata absolut (Mo), rata-rata ideal (Mi) dan standar deviasi ideal (Sdi).

Berdasarkan data hasil penelitian Hasil Menggambar Busana Kreasi diperoleh Mo sebesar 24,16; Mi sebesar 20 dan Sdi sebesar 4. Berdasarkan hasil perhitungan diperoleh kelas kecenderungan Hasil Menggambar Busana Kreasi (Y) sebagai mana disajikan pada tabel . Perhitungan selengkapnya ada pada lampiran 13 halaman 105.

\begin{tabular}{|c|c|c|c|}
\hline Kelompok & fo & Fr & Kategori \\
\hline $26-$ Ke atas & 13 & $41,94 \%$ & Tinggi \\
\hline $20-25$ & 15 & $48,39 \%$ & Cukup \\
\hline $14-19$ & 3 & $9,68 \%$ & Kurang \\
\hline $13-$ Ke bawah & 0 & $0,00 \%$ & Rendah \\
\hline Jumlah & 31 & $100,00 \%$ & \\
\hline
\end{tabular}

Tabel 8.Hasil Menggambar Busana Kreasi

Dari tabel 7 dilihat bahwa kategori tinggi ada 13 orang (41,94\%), kategori cukup ada 15 orang $(48,39 \%)$.
Dengan demikian dapat disimpulkan bahwa Persentasi Hasil Menggambar Busana Kreasi (Y) pada Siswa SMK Negeri 8 Medan berada dalam kategori Cukup.Jadi dapat disimpulkan Mo > Mi yaitu 24,16>Mi 20. Dan berdasarkan hasil perhitungan tersebut dapat disimpulkan bahwa siswi kelas XI SMK Negeri 8 Medan, Hasil Menggambar Busana Kreasi (Y) Berada dalam kategori cukup yang berarti bahwa data hasil penelitian mengenai Pengetahuan Desain Busana cenderung berada pada rata-rata ideal.

\section{Uji Normalitas}

Uji normalitas bertujuan untuk mengetahui normal tidaknya data setiap variabel penelitian. Pengujian ini dilakukan dengan rumus Liliefors (taraf $\alpha=0,05$ ). Adapun kriteria pengujian normalitas ini adalah jika $\mathrm{L}_{\text {Hitung }}<\mathrm{L}_{\text {Tabel }}$ maka sampel berdistribusi normal dan jika $\mathrm{L}_{\text {Hitung }}>\mathrm{L}_{\text {Tabel }}$ maka sampel tidak berdistribusi normal.

Data hasil penelitian Pengetahuan Desain Busana (X) adalah berdistribusi normal yang dibuktikan dengan uji normalitas dimana diperoleh nilai $\mathrm{L}_{\text {Hitung }} 0,1430<\mathrm{L}_{\text {Tabel }}$ 0,1591. Data hasil penelitian Menggambar Busana Kreasi (Y) juga berdistribusi normal yang dibuktikan dengan uji normalitas dimana diperoleh $\mathrm{L}_{\text {Hitung }} 0,1575<\mathrm{L}_{\text {Tabel }}$ 0,1591 .

\section{Uji Linieritas dan Keberartian Regresi}

Uji liniearitas ini dilakukan untuk mengetahui linier atau tidaknya hubungan variabel bebas dengan variabel terikat yang merupakan syarat untuk menggunakan teknik statistik dan analisis regresi, yaitu variabel Pengetahuan Desain Busana (X) dan Hasil Menggambar Busana Kreasi (Y). Dalam penelitian ini terdapat satu variabel bebas yang diduga dapat mempengaruhi variabel terikat, sehingga ada satu persamaan regresi yang perlu diuji kelinieran dan keberartiannya masing-masing, yaitu variabel Y terhadap X.

Berikut disajikan ringkasan analisis varians yang menguji kelinieran dan keberartian persamaan regresi Hasil Menggambar Busana Kreasi (Y) atas Pengetahuan Desain Busana (X). 
Hubungan pengetahuan desain busana dengan hasil Menggambar busana kreasi pada siswa Smk negeri 8 medan

\begin{tabular}{|c|c|c|c|c|c|}
\hline $\begin{array}{l}\text { Sumber } \\
\text { Varians }\end{array}$ & $\begin{array}{l}\mathrm{D} \\
\mathrm{k}\end{array}$ & JK & RJK & $\underset{\mathrm{ng}}{\mathrm{F}_{\mathrm{Hitu}}}$ & $\begin{array}{c}\mathrm{F}_{\text {Tabel }} \\
\alpha= \\
0,05\end{array}$ \\
\hline Total & 31 & 18329 & & & \\
\hline $\begin{array}{l}\text { Regresi } \\
\text { (a) }\end{array}$ & 1 & 18096,81 & & & \\
\hline $\begin{array}{l}\text { Regresi } \\
\text { (b/a) }\end{array}$ & 1 & 48,45 & 48,45 & 7,65 & 4,18 \\
\hline $\begin{array}{l}\text { Residu } \\
\text { (s) }\end{array}$ & 29 & 183,74 & 6,34 & & \\
\hline $\begin{array}{l}\text { Tuna } \\
\text { cocok } \\
\text { (TC) }\end{array}$ & 10 & 62,66 & 6,27 & 0,98 & 2,38 \\
\hline Galat (G) & 19 & 121,08 & 6,37 & & \\
\hline
\end{tabular}

Tabel 10. Ringkasan Anava untuk Persamaan Regresi Y atas X

Dari table 10 di atas dapat dilihat bahwa $\mathrm{F}_{\text {Tabel }}$ dengan dk (10:19) pada $\alpha=0,05$ adalah 2,38 sedangkan $\mathrm{F}_{\text {Hitung }}$ yang diperoleh adalah 0,98 dan ternyata $F_{\text {Hitung }} 0,98<\mathrm{F}_{\text {Tabel }} 2,38$ sehingga persamaan regresi tersebut adalah linier. Selanjutnya untuk uji keberartian regresi dengan dk (1:29) pada $\alpha=0,05$ diperoleh $\mathrm{F}_{\text {Tabel }}=4,18$ sedangkan $\mathrm{F}_{\text {Hitung }}$ yang diperoleh adalah 7,65 dan ternyata $F_{\text {Hitung }} 7,65>$ $\mathrm{F}_{\text {Tabel }} 4,18$ sehingga persamaan regresi $\mathrm{Y}$ atas $\mathrm{X}$ adalah berarti. Dengan demikian dapat disimpulkan bahwa persamaan regresi $\hat{Y}=18,18+0,10 X$ mempunyai hubungan yang linier dan berarti pada $\alpha$ $=0,05$.

\section{D.Pengujian Hipotesis}

Adapun hipotesis yang diajukan dalam penelitian ini adalah "Terdapat Hubungan yang signifikan antara Pengetahuan Desain Busana dengan Hasil Menggambar Busana Kreasi sumber ide gelas platik pada siswa kelas XI program studi Tata Busana SMK Negeri 8 Medan ".

Untuk melihat hubungan yang signifikan antara Pengetahuan Desain Busana (X) dengan Hasil Menggambar Busana Kreasi (Y) maka dilakukan uji hipotesis dengan uji $\mathrm{t}$ data hasil penelitian. Berdasarkan hasil analisis uji $\mathrm{t}$ dengan koefisien korelasi $r_{1 y}$ sebesar 0,457 diperoleh nilai $t_{\text {Hitung }}$ sebesar 2,77. Pengujian hipotesis Ho diterima jika $\mathrm{t}_{(1-1 / 2 \alpha)}<\mathrm{t}_{\text {Hitung }}<\mathrm{t}_{(1-1 / 2 \alpha)}$, dimana distribusi $\mathrm{t}$ yang digunakan mempunyai $\mathrm{dk}=(\mathrm{n}-2)$ dan Ho ditolak untuk kondisi sebaliknya. Oleh karena harga $t_{\text {hitung }}$

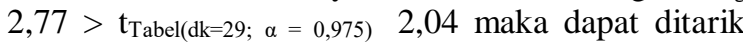
kesimpulan bahwa Ho ditolak dan sekaligus menerima Ha yaitu terdapat hubungan yang positif dan signifikan antara Pengetahuan Desain Busana (X) dengan Hasil Menggambar Busana Kreasi (Y).

Berdasarkan uraian diatas maka hipotesis penelitian berbunyi "Terdapat Hubungan Antara Pengetahuan Desain Busana dengan Hasil Menggambar Busana Kreasi Sumber ide gelas plastic pada siswa kelas XI program studi Tata Busana SMK Negeri 8 Medan”.

\section{E. Hasil Penelitian}

1. Hasil perhitungan yang diperoleh dari data Pengetahuan desain busana (X) adalah diperoleh rata-rata skor sebesar 58,49 dan standar deviasi 12,44 dan untuk hasil menggambar busana kreasi (Y) diperoleh rata-rata skor sebesar 24,14 dan standar deviasi 2,86.

2. Identifikasi tingkat kecenderungan Pengetahuan desain busana (X) berada dalam kategori cukup dan hasil menggambar busana kreasi (Y) tergolong dalam kategori cukup.

3. Persamaan regresi linier atas pengetahuan desain busana dengan hasil menggambar busana kreasi $\ddot{Y}=18,18+0,10 \mathrm{X}$

Hasil uji hipotesis yang menyatakan terdapat hubungan yang signifikan antara Pengetahuan Desain Busana dengan Hasil Menggambar Busana Kreasi pada Siswa Kelas XI Jurusan Tata Busana SMK Negeri 8 Medan. Dari tabel $r$ dengan taraf signifikan $\propto 0,05$ dengan jumlah reponden 31 orang. Diperoleh $r t_{a b e l}$ sebesar 0,35. Dengan demikian harga $r_{\text {hitung }} 0,457>r_{\text {Tabel }} 0,355$ sehingga koefisien korelasi $\mathrm{X}$ terhadap $\mathrm{Y}$ adalah signifikan. Sesuai dengan kriteria penerimaan dan penolakan hipotesis , maka hipotesis kerja (Ha) yang diajukan diterima pada taraf signifikan 5\%. Dengan demikian dinyatakan terdapat Korelasi yang berarti antara Pengetahuan Desain Busana (X) dengan Hasil Menggambar Busana Kreasi (Y)

\section{F.Pembahasan Penelitian}

Hasil penelitian ini mengungkapkan terdapat yang positif dan signifikan antara Pengetahuan Desain Busana dengan Hasil Menggambar Busana Kreasi. Hasil analisis data korelasi Pengetahuan Desain Busana (X) dengan Hasil Menggambar Busana Kreasi (Y), ternyata memiliki bentuk hubungan linier, yaitu : $\hat{Y}=18,18+0,10 X$ yang dibuktikan dengan nilai $F_{\text {Hitung }} 0,98<\mathrm{F}_{\text {Tabel }} 2,38$ sehingga persamaan regresi tersebut adalah linier. Selanjutnya untuk uji keberartian regresi diperoleh $F_{\text {Hitung }}$ 7,65 $>F_{\text {Tabel }} 4,18$ sehingga persamaan regresi $\mathrm{Y}$ atas $\mathrm{X}$ adalah berarti. Apabila dilanjutkan pada analisis koefisien korelasi antara $\mathrm{Y}$ dan $\mathrm{X}$, maka nilai koefisien korelasi sebesar 0,457 dan $\mathrm{r}_{\text {Tabel }}$ untuk jumlah responden sebanyak 31 orang sebesar 0,355 pada taraf signifikansi 5\%. Dengan demikian diperoleh $r_{\text {hitung }} 0,457>r_{\text {Tabel }} 0,355$ sehingga koefisien korelasi $\mathrm{X}$ terhadap $\mathrm{Y}$ adalah signifikan. Selanjutnya, hasil analisis keberartian koefisien korelasi antar variabel $\mathrm{X}$ dengan $\mathrm{Y}$ diperoleh nilai $\mathrm{t}_{\text {Hitung }}$ sebesar 2,77 dan dikonsultasikan dengan nilai $\mathrm{t}_{\text {Tabel }(\mathrm{dk}=29 ; \alpha=0,05)}$ sebesar 2,04 sehingga diperoleh $\mathrm{t}$ Hitung $>\mathrm{t}$ Tabel $(2,77>2,04)$. Sesuai dengan hal tersebut dapat dikatakan bahwa terdapat korelasi 
Hubungan pengetahuan desain busana dengan hasil Menggambar busana kreasi pada siswa Smk negeri 8 medan

yang berarti antara variabel $\mathrm{X}$ dengan $\mathrm{Y}$. Dengan demikian dapat dijelaskan bahwa terdapat hubungan fungsional yang signifikan dari Pengetahuan Desain Busana (X) dengan Hasil Menggambar Busana Kreasi (Y). Bentuk kontribusi tersebut berarah positif, berarti "semakin baik Pengetahuan Desain Busana maka akan semakin baik pula Hasil Menggambar Busana Kreasi, begitu juga sebaliknya".

\section{A. Kesimpulan}

Berdasarkan hasil penelitian yang di uraikan pada bab IV, maka dapat disimpulkan sebagai berikut:

1. Tingkat kecenderungan Pengetahuan Desain Busana Siswa SMK Negeri 8 Medan dalam kategori cukup.

2. Tingkat kecenderungan Hasil Menggambar Busana Kreasi Siswa SMK Negeri 8 Medan adalah kategori cukup.

3. Hasil analisis diketahui bahwa terdapat hubungan yang signifikan antara Pengetahuan Desain Busana dengan Hasil Menggambar Busana Kreasi pada siswa kelas XI Jurusan Tata Busana sebesar 0,457.

\section{B.Implikasi}

Berdasarkan hasil penelitian dan kesimpulan penelitian maka diberikan implikasi yaitu dengan diterimanya hipotesis penelitian, maka perlu kiranya menjadi pertimbangan bagi para Siswa SMK Negeri 8 Medan untuk meningkatkan Pengetahuan Desain Busana yang meliputi penguasaan tentang rancangan suatu gagasan di bidang busana sehingga secara langsung dapat meningkatkan Hasil Menggambar Busana Kreasi.

\section{C.Saran}

Berdasarkan kesimpulan tersebut diatas maka tindak lanjut penelitian ini disarankan hal hal sebagai berikut:

1. Bagi para siswa SMK Busana khususnya SMK Negeri 8 untuk dapat lebih meningkatkan pengetahuannya mengenai Desain Busana agar Hasil Menggambar Busana Kreasinya juga menjadi lebih baik.

2. Bagi peneliti lanjutan yang melakukan penelitian lanjutan sejenis agar lebih memperhatikan karakter para siswa SMK Negeri 8 khususnya yang terkait dengan Pengetahuan Desain Busana dan Hasil Menggambar Busana Kreasi.

\section{DAFTAR PUSTAKA}

Arikunto, Suharsimi. 2003. Pengantar Dasar-dasar Evaluasi Pendidikan. Jakarta: Bumi Aksara.

Arikunto, Suharsimi. 2010. Prosedur Penelitian, Suatu Pendekatan Praktek. Jakarta : Rineka Cipta.

Basuki, Lanawati. Soekarno. 2004. Panduan Membuat Desain Ilustrasi Busana. Tangerang : PT Kawan Pustaka.

Chodiah. 2000. Seni Dalam Desain Pakaian dan Desain Hiasan. Jakarta : IKIP

Depdiknas. 2002. Kamus Besar Bahasa Indonesia. Jakarta : Balai Pustaka.

Dwioktavia, 2011. Pemanfaatan limbah Plastik (online). www. Pemanfaatan limbah Plastik.com, diakses pada tanggal 12 Desember 2012.

Ernawati, dkk. Pengertian Busana (Online). www. Pengertian Busana.com, diakses pada tanggal 06 September 2009.

http://adhe-fashion.blogspot.com/ (diunduh tanggal 16 Februari 2013)

http://Sketsa Desain Dress. Blogspot.com/ (diunduh pada tanggal 16 Februari 2013)

http://dwioktavia.wordpress.com/2011/04/14/pengol ahan-limbah-plastik/(diunduh pada tanggal 04 September 2012).

Irianto, Agus. 2010. Statistika. Kencana Prenada Media Group, Jakarta.

Jumanta. 2005. Pola Flora Dan Geometris Untuk Sulam Dan Bordir. Jakarta : Puspa Swara.

Jusuf, Herman. 1995. Desain Busana dan Model I. Bandung : ITB

Mu'in. 2004. Teori Busana. Bandung : Yapembda

Muliawan, Porrie. 2002. Menggambar Mode Dan Mencipta Busana Wanita. Jakarta : PT. BPK Gunung Mulia

Okrek. 2009. Pengertian Desain Busana (online), http/okrek.blogspot.com/2009/12/Pengertia n-desain-Busana.html, diakses pada tanggal 08 Februari 2013

Riyanto, Afifa . 2003. Desain Busana. Bandung : Penerbit Yapemdo.

Soekarno dan Basuki. 2004. Panduan Membuat Desain Ilustrasi Busana. Jakarta : PT. Kawan Pustaka.

Sudijono, Anas. 2009. Pengantar Evaluasi Pendidikan. Jakarta : PT Raja Grafindo Persada.

Sudjana, 2002. Teknik Analisis Regresi Dan Korelasi. Bandung : Tarsito.

Usman, H. Setiady, R.P.1995. Pengantar Statistika. Jakarta: Bumi Aksara.

Walgito. 2003. Media Pendidikan Pengertian, Pengembangan dan Pemanfaatan. Jakarta : PT. Raja Grafindo Persada.

Winari, 2001. Merancang Anatomi Modis (online), http/okrek.blogspot.com/2001/12/Merancan 
Hubungan pengetahuan desain busana dengan hasil Menggambar busana kreasi pada siswa Smk negeri 8 medan

g-Anatomi-Modis.html, diakses pada tanggal 08 Februari 2013)

Yanti. 2012. Daur Ulang 'Sulap Sampah Menjadi

Barang Bermanfaat'. Jakarta : Demedia Pustaka. 